\title{
DUKUNGAN KELUARGA DALAM \\ PERILAKU PELAYANAN KESEHATAN
}

\section{Oleh: \\ WIDA SILVIA \\ Program Studi Kesehatan Masyarakat Universitas Faletehan}

\section{Latar Belakang}

Pemanfaatan pelayanan kesehatan merupakan hasil dari proses pencarian pelayanan kesehatan oleh seseorang maupun kelompok. Di bidang kesehatan, analisis pemanfaatan pelayanan kesehatan berguna untuk mengetahui pola pemanfaatan (penggunaan) pelayanan kesehatan oleh masyarakat. Informasi ini berguna sebagai masukan bagi para pengambil keputusan untuk merencanakan dan mengelola pelayanan kesehatan agar lebih efektif dan efisien.(Notoatmodjo, 2003)

Masyarakat membutuhkan pelayanan kesehatan dan informasi tentang masalah kesehatan yang dihadapinya. Faktor manusia dalam hal ini memegang peranan sangat penting dalam penciptaan perilaku pemanfaatan pelayanan kesehatan. (Hayat et al., 2021) Menurut Andersen (1995) tentang model perilaku pelayanan kesehatan (behavioral model of health services utilization), terdapat tiga faktor utama yang berpengaruh terhadap pelayanan kesehatan yaitu; 1) presdiposing characteristic, diantaranya ciri demografi (demographic) seperti umur, jenis kelamin, dan status perkawinan, struktur sosial (social structure) seperti tingkat pendidikan, pekerjaan, hobi, ras, agama), kepercayaan kesehatan (health beliefe) seperti keyakinan bahwa pelayanan kesehatan dapat menolong proses penyembuhan penyakit; 2) enabling characteristics, diantaranya sumber daya keluarga (family resources) seperti penghasilan keluarga, keikutsertaan dalam asuransi kesehatan, kemampuan membeli jasa pelayanan kesehatan,dan pengetahuan tentang informasi pelayanan kesehatan yang dibutuhkan serta sumber daya masyarakat (community resources) seperti jumlah sarana kesehatan 
yang ada, jumlah tenaga kesehatan yang tersedia dalam wilayah tersebut, rasio penduduk terhadap tenaga kesehatan, dan lokasi tempat tinggal); 3) need characteristics diantaranya penilaian individu (perceived need) yaitu penilaian kondisi kesehatan yang dirasakan oleh individu, besarnya ketakutan terhadap penyakit dan hebatnya rasa sakit yang diderita, penilaian klinik (evaluated need), diantaranya penilaian beratnya penyakit dari dokter yang merawatnya,tercermin dari hasil pemeriksaan dan penentuan diagnosis penyakit oleh dokter.

Pengaruh Predisposing Factor, Enable Factor, Reinforcing Factor, terhadap Praktik Keselamatan Kerja pada Tenaga Kesehatan Dalam Pengelolaan Limbah Medis Padat di Puskesmas. (Hayat, 2012)

Dukungan keluarga merupakan sikap, tindakan dan penerimaan keluarga terhadap penderita yang sakit, anggota keluarga memandang bahwa orang yang bersifat mendukung selalu siap memberikan pertolongan dan bantuan jika dibutuhkan. Dukungan keluarga berupa dukungan penilaian, instrumental, informasional dan dukungan emosional.(Triyani \& Warsito, 2019)

\section{Hasil Kajian}

Perilaku pemanfaatan pelayanan kesehatan gizi oleh ibu hamil dengan risiko KEK disebabkan oleh faktor dukungan suami. Peran suami dalam perilaku pemanfaatan pelayanan gizi sangat penting, suami sebagai orang terdekat dengan ibu hamil sebagai motivator untuk memeriksakan kehamilannya serta mendukung ibu hamil baik secara moril maupun materil, sehingga ibu dapat melalui kehamilannya dengan baik. (Hayat et al., 2021)

Faktor dukungan keluarga terhadap pencegahan kekambuhan gangguan jiwa. Hasil penelitian menunjukkan bahwa Pencegahan kekambuhan gangguan jiwa berhubungan dengan dukungan keluarga diantarannya dukungan informasi $(\mathrm{p}=0,002)$, dukungan penilaian $(\mathrm{p}=0,003)$, dukungan emosional $(\mathrm{p}=0,006)$, dukungan instrumental (0,03). Kesimpulan; Ada hubungan antara dukungan keluarga dengan pencegahan kekambuhan gangguan jiwa di Kecamatan Padarincang Kabupaten Serang.(Hayat \& Kusuma, 2021) 
Perubahan perilaku dan perbaikan kondisi sanitasi lingkungan berperan penting dalam upaya pencegahan dan pengendalian penyakit tuberkulosis paru BTA (+). Hasil analisis menunjukkan bahwa Pengetahuan, dukungan keluarga dan faktor kebutuhan merupakan faktor yang dominan berpengaruh terhadap pelayanan klinik sanitasi puskesmas oleh keluarga penyakit tuberkulosis paru (BTA+).(Kurniatillah \& Hayat, 2021)

Pengaruh signifikan antara Peran Orang Tua terhadap Pemberian Vaksin Covid19 pada Siswa Kelas XI di MAN I Kota Serang. Hal ini dibuktikan dengan perolehan nilai sig $=0,015<0,05$ dan F-hitung $=6,648$. Dapat disimpulkan bahwa peran orang tua membawa dampak terhadap pemberian vaksin Covid19.(Kurniatillah et al., 2022)

Pengaruh pengetahuan $(\mathrm{p}=0,016)$ dan pengawasan $(\mathrm{p}=0,004)$ dengan penggunaan formalin pada pedagang tahu. Penegakan aturan, dukungan dan pembinaan pedagang dan produsen tahu mencegah penggunaan formalin.(Hayat \& Darusmini, 2021)

\section{Kesimpulan}

Masyarakat membutuhkan pelayanan kesehatan dan informasi tentang masalah kesehatan yang dihadapinya. Faktor manusia dalam hal ini memegang peranan sangat penting dalam penciptaan perilaku pemanfaatan pelayanan kesehatan.

\section{Referensi}

Hayat, F. (2012). Pengaruh predisposing factor, Enable factor, Reinforcing factor terhadap praktik keselamatan kerja pada tenaga kesehatan dalam pengelolaan limbah medis padat di Puskesmas Wilayah Kota Cilegon tahun 2011. In Unpad Repository. Unpad.

Hayat, F., Arifiati, N., \& Permatasari, T. A. E. (2021). Peran Dukungan Suami dan Faktor Lainnya terhadap Pemanfaatan Pelayanan Gizi oleh Ibu Hamil dengan Risiko Kurang Energi Kronis (KEK). Jurnal Keperawatan Silampari, 5(1), 125-133. 
Hayat, F., \& Darusmini, D. (2021). ANALISIS FAKTOR PENGGUNAAN FORMALIN PADA PEDAGANG TAHU DI PASAR TRADISIONAL KOTA SERANG. Jurnal Surya Muda, 3(2), 121-132.

Hayat, F., \& Kusuma, A. N. (2021). FAKTOR DUKUNGAN KELUARGA TERHADAP PENCEGAHAN KEKAMBUHAN GANGGUAN JIWA DI KECAMATAN PADARINCAANG KABUPATEN SERANG. IAKMI Jurnal Kesehatan Masyarakat Indonesia, 2(3), 111-118.

Kurniatillah, N., \& Hayat, F. (2021). ANALISIS PERILAKU PEMANFAATAN PELAYANAN KLINIK SANITASI PUSKESMAS OLEH KELUARGA DENGAN PENYAKIT TUBERKULOSIS PARU BTA (+) DI KECAMATAN TAKTAKAN KOTA SERANG. JOURNAL OF BAJA HEALTH SCIENCE, 1(02), 107-114.

Kurniatillah, N., Hayat, F., \& Nurjaman, N. (2022). Pengaruh Peran Orang Tua Terhadap Pemberian Vaksinasi Covid 19 di MAN I Kota Serang. JOURNAL OF BAJA HEALTH SCIENCE, 2(01), 18-23.

Notoatmodjo, S. (2003). Pendidikan dan perilaku kesehatan.

Triyani, F. A., \& Warsito, B. E. (2019). Peran Dukungan Keluarga dalam Pencegahan Kekambuhan Pasien Skizofrenia: Literatur Review. Jurnal Ilmu Keperawatan Indonesia (JIKI), 12(1). 